\title{
Quality for fresh consumption and processing of some non-traditional tropical fruits from Brazil
}

\author{
Maria do Socorro Moura Rufino ${ }^{1}$, Ricardo Elesbão Alves ${ }^{2 *}$, Edy Sousa de Brito ${ }^{2}$, Márcia Régia Souza da SILVEIRA ${ }^{2}$, \\ Carlos Farley Herbster MOURA ${ }^{2}$
}

\author{
${ }^{1}$ Fed. Rural Univ. Semi-Arid, \\ BR 110, Km 47, Pres. Costa e \\ Silva, 59625-900, \\ Mossoró - RN, Brazil \\ marisrufino@yahoo.com.br \\ 2 Embrapa Trop. Agroind., R. \\ Dra. Sara Mesquita, 2270, Pici, \\ 60511-110, Fortaleza - CE, \\ Brazil \\ elesbao@pq.cnpq.br
}

Quality for fresh consumption and processing of some non-traditional tropical fruits from Brazil.

Abstract - Introduction. Brazil is home to a great diversity of tropical, non-traditional fruit species with a potential for consumption in natura and agroindustrial processing. The objective of our study was to evaluate the quality of 18 non-traditional fruits from Brazil belonging to the families Anacardiaceae, Apocynaceae, Arecaceae, Clusiaceae, Malpighiaceae, Melastomataceae and Myrtaceae. Materials and methods. Samples were collected from areas of occurrence, commercial orchards and collections in Northern, Northeastern and Southeastern Brazil; they were tested for total soluble solids (TSS), soluble sugars (SS), reducing sugars (RS), total titratable acidity (TTA), pH, [TSS / TTA] ratio, starch, total pectin (TP) and soluble pectin (SP). Results and discussion. Parameters varied greatly among the species. Thus, TSS was 4.75-37.07 ${ }^{\circ}$ Brix; SS, 1.26-17.74\%; RS, 2.53-9.92\%; TTA, 0.20-2.64\%; pH, 2.56-5.38; [TSS / TTA], 3.26-107.70; starch, 0.12-12.65\%; TP, 0.15-1.27\%; and SP, 0.04-1.49\%. Conclusion. Many of the 18 fruits evaluated in this study show potential for consumption in natura and agroindustrial processing.

Brazil / tropical fruits / indigenous species / introduced varieties / production possibilities / consumption / fresh fruits / processing

\section{Qualité de quelques fruits tropicaux non traditionnels du Brésil consommés frais ou après transformation.}

Résumé - Introduction. Le Brésil possède une grande diversité d'espèces fruitières tropicales non traditionnelles potentiellement consommables en fruits frais ou après transformation. L'objectif de notre étude a été d'évaluer la qualité de 18 fruits non traditionnels du Brésil appartenant aux familles Anacardiaceae, Apocynaceae, Arecaceae, Clusiaceae, Malpighiaceae, Melastomataceae et Myrtaceae. Matériel et méthodes. Des échantillons ont été collectés sur leur lieu de production, en vergers commerciaux et en collections, dans le nord, nord-est et sud-est du Brésil. Les fruits ont été analysés pour évaluation de leurs caractéristiques : solides solubles totaux (SST), sucres solubles (SS), sucres réducteurs (SR), acidité totale titrable (ATT), $\mathrm{pH}$, rapport [SST / ATT], amidon, pectine totale (PT) et pectine soluble (PS). Résultats et discussion. Les caractéristiques ont considérablement varié parmi les espèces étudiées. Ainsi, les SST ont été de 4,75-37,07 ${ }^{\circ}$ Brix ; SS, 1,26-17,74\% ; SR, 2,53-9,92\%; TTA, 0,20-2,64\% ; pH, 2,56-5,38 ; [SST / ATT], 3,26-107,70\% ; amidon, 0,12-12,65\% ; PT, 0,15-1,27\% ; et PS, 0,04$1,49 \%$. Conclusion. Plusieurs des 18 fruits évalués lors de cette étude offriraient un bon potentiel pour une consommation en fruits frais ou après transformation.

Fruits, 2009, vol. 64, p. 361-370 (C) 2009 Cirad/EDP Sciences All rights reserved DOI: $10.1051 /$ fruits/2009032 www.fruits-journal.org

RESUMEN ESPAÑoL, p. 370
Brésil / fruits tropicaux / espèce indigène / variété introduite / possibilité de production / consommation / fruits frais / traitement 


\section{Introduction}

There are a great number of underexploited, non-traditional fruits in the world $[1,2]$ Especially many tropical fruit species remain virtually unknown and absent from international markets [3]. It is estimated that a quarter million plant species have been described around the globe, sixty thousand in Brazil alone - the country with the world's greatest plant diversity. Nearly one thousand fruit species belonging to 80 families are known from the Americas. At least half of these occur in or stem from Brazil. Most have been little studied [4] or never studied.

Northern and Northeastern Brazil feature many non-traditional fruits with attractive commercial aspects. Production is not

Figure 1.

Brazilian tropical, nontraditional fruits of the Anacardiaceae family.

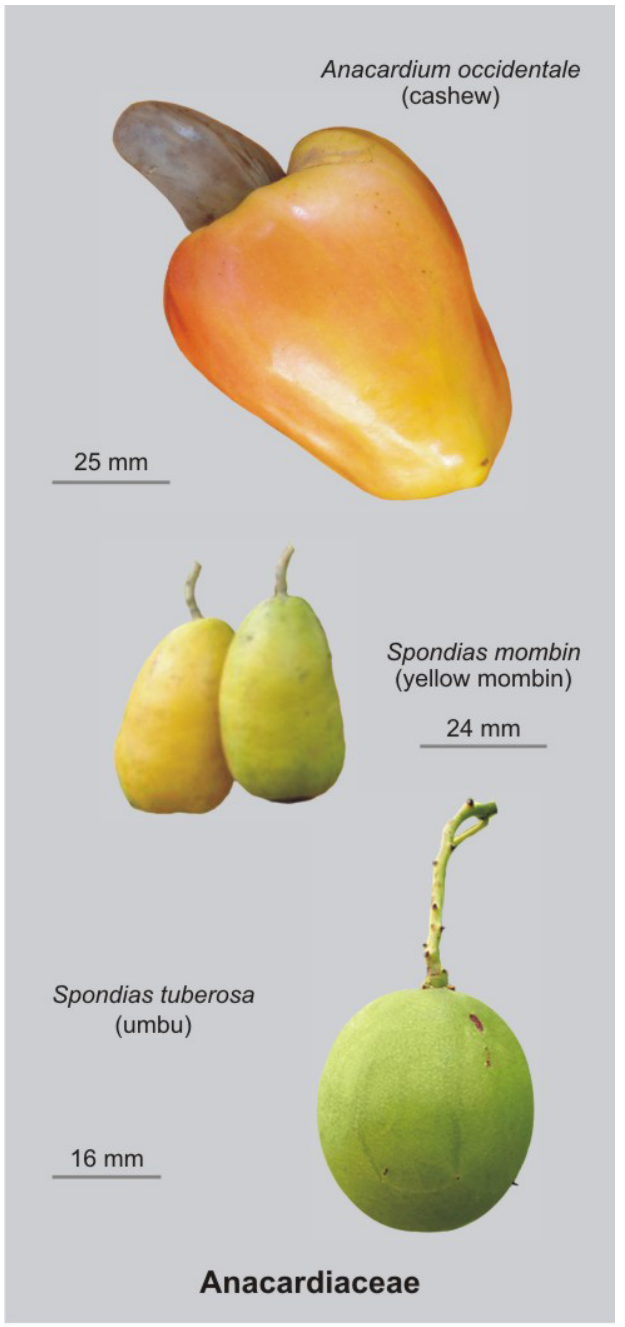

always limited to extraction, but rational culture is increasing throughout the country. Some species already play an important role in tropical fruit agrobusiness and are produced for both consumption in natura and agroindustrial processing [5].

In fact, the Brazilian flora is rich in fruit species with promising potential for agriculture, genetic improvement and domestication. The genetic variability remains underexploited compared with the strategic value it represents for the development of new products. Also, as natural populations of fruit trees are endangered by an array of environmental impacts, conservation policies and actions will be necessary to ensure survival and sustainable economic use [6].

However, domestication and agricultural expansion will primarily depend on the development of essential technical information on these fruit species, ranging from chemical composition to quality seedling production and post-harvest conservation. Thus, the objective of our study was to evaluate the quality properties of 18 non-traditional fruits from Brazil with potential for consumption in natura and agroindustrial processing.

\section{Materials and methods}

\subsection{Chemicals}

The reagents used were 9,10-dihydro-9oxoanthracene (anthrone) from Merck (Hohenbrunn, German); D-(+)-galacturonic acid from Fluka Biochemika (Steinheim, German); 3,5-dinitrosalicylic acid (DNS) from Aldrich (Steinheim, German); D-(+)glucose anhydrous from Vetec (Rio de Janeiro, Brazil); and m-hydroxydiphenyl from Fluka Biochemika (Steinheim, German). All reagents were of analytical grade.

\subsection{Samples}

Samples were collected from areas of occurrence, commercial orchards and collections in Northern, Northeastern and Southeastern Brazil.

Eighteen fruits were included in the study (figures 1-O) and identified with their 
common names, family and sample origin (table I). Fruits were harvested at the commercial maturity stage (completely ripe) and sent to the laboratory for pulp extraction.

Two fruits (assai and jussara, figure 2) required special processing due to their highly fibrous epicarp and endocarp and small edible percentage $(<30 \%)$. Their pulp and fiber were mechanically separated with a knife and weighed, then distilled water was added (1:2). The mass was homogenized and the inedible parts were discarded. Bacuri pulp (figure 3) was extracted manually with a knife and scissors, and the husk and seed were discarded. For the other fifteen fruits, the pulp and peel were processed and only the seeds were discarded. The final results are reported on a wet weight basis.

\subsection{Methods}

Total soluble solids (TSS) was determined on the filtered pulp; it was analyzed using a digital refractometer (Atago PR-101) with a 0-45 ${ }^{\circ}$ Brix scale [7]. To assess the soluble sugar (SS) content, $1 \mathrm{~g}$ of pulp was diluted in water and/or 80\% ethanol and evaluated by the Anthrone method using glucose as a standard. Readings were taken with a Spectronic Genesys 2 spectrophotometer at $620 \mathrm{~nm}$. Results were expressed in \% (g glucose $100 \mathrm{~g}^{-1}$ edible portion) [8]. Reducing sugar (RS) concentration was measured from $1 \mathrm{~g}$ of pulp diluted in water and/or 80\% ethyl alcohol and determined by the DNS method using glucose as a standard. Readings were taken with a spectrophotometer at $540 \mathrm{~nm}$. Results were expressed in $\mathrm{g}$ glucose $\cdot 100 \mathrm{~g}^{-1}$ edible portion [9].

Following titration with $0.1 \mathrm{~N} \mathrm{NaOH}$ to a final $\mathrm{pH}$ of 8.1 , total titratable acidity (TTA) readings were taken with an automatic Mettler potentiometer (model DL 12) and the results were expressed in $\mathrm{g}$ acid $\cdot 100^{-1} \mathrm{~g}$ edible portion. For acerola fruit and cashew apples the values were expressed as malic acid and for all the remaining fruits as citric acid [10]. pH was measured directly in the pulp following processing. Readings were taken with an automatic Mettler potentiometer (model DL 12), adjusted with buffer solutions at $\mathrm{pH} 4$ and $\mathrm{pH} 7$ [7]. The

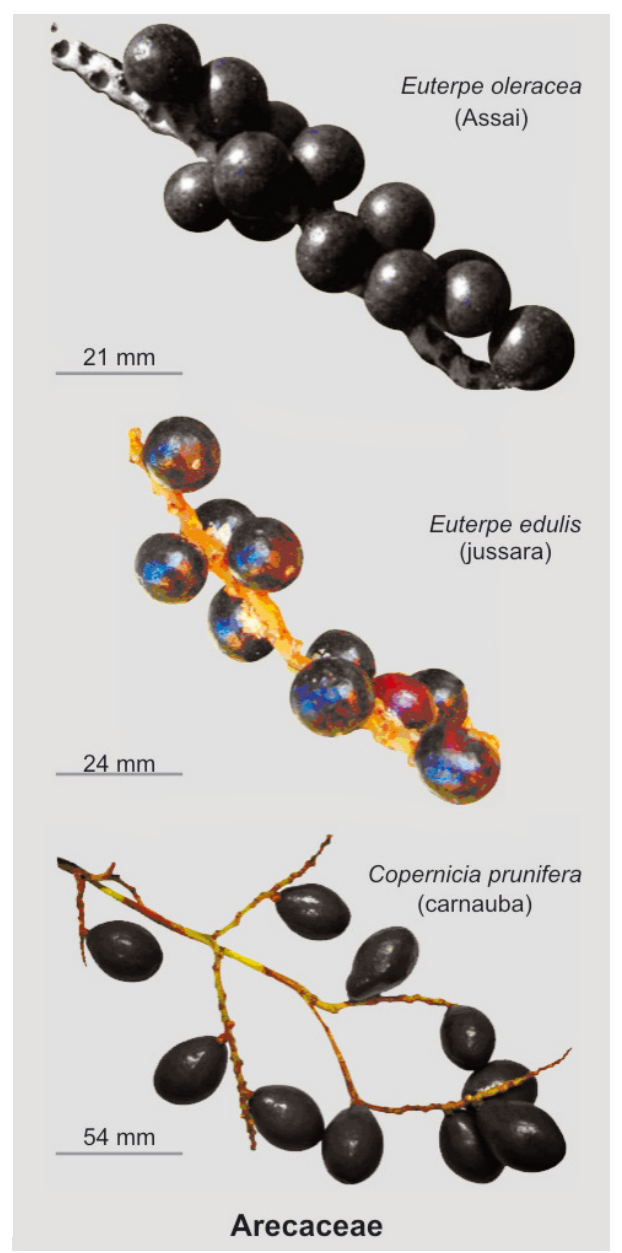

Figure 2.

Brazilian tropical, nontraditional fruits of the Arecaceae family.

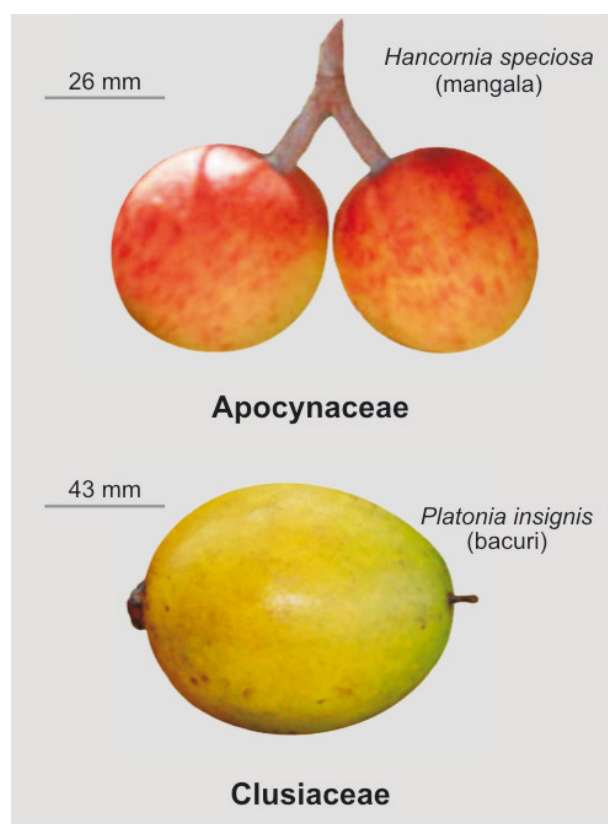

Figure 3.

Brazilian tropical, nontraditional fruits of the Apocynaceae and Clusiaceae families. 
Figure 4.

Brazilian tropical, nontraditional fruits of the Malpiguiaceae family.

Figure 5.

Brazilian tropical, nontraditional fruits of the Melastomataceae family.
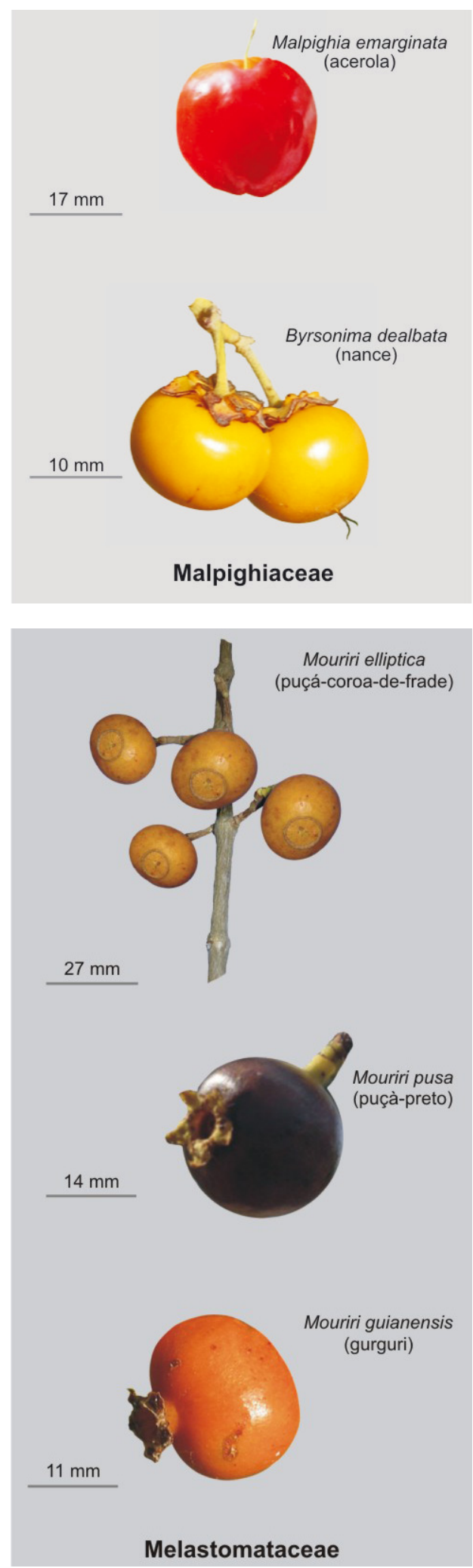

[TSS / TTA] ratio was calculated by dividing TSS by TTA.

To measure the starch content, the residue from centrifugation at $3000 \mathrm{~g}$ was extracted under reflux by hydrolysis with $\mathrm{HCl}$ for $2 \mathrm{~h}$, then neutralized with $20 \%$ sodium carbonate solution. The final concentrations were determined by the DNS method using glucose as a standard. Readings were taken with a spectrophotometer at $540 \mathrm{~nm}$. Results were expressed in $\mathrm{g}$ glucose $\cdot 100 \mathrm{~g}^{-1}$ edible portion [7].

Total pectin (TP) was assessed from the pulp weighed and homogenized with 95\% ethyl alcohol. The residue was centrifuged with $75 \%$ ethyl alcohol and adjusted with 1.0 $\mathrm{N} \mathrm{NaOH}$ to $\mathrm{pH} 11.50$ and with glacial acetic acid to $\mathrm{pH} 5.0-5.5(15: 50 \mathrm{v} / \mathrm{v})$. Pectinase was added to the extract and submitted to enzyme hydrolysis for $1 \mathrm{~h}$ under shaking. Following centrifugation, concentrations were determined by the m-hydroxy-diphenyl method using galacturonic acid as a standard. Readings were taken with a spectrophotometer at $520 \mathrm{~nm}$. Results were expressed in g galacturonic acid $100 \mathrm{~g}^{-1}$ edible portion [11, 12]. For soluble pectin (SP) measurements, the pulp was weighed and homogenized with 95\% ethyl alcohol and the residue was centrifuged with $75 \%$ ethanol. The extract was diluted in water and concentrations were determined with the mhydroxy-diphenyl method using galacturonic acid as a standard. Readings were taken with a spectrophotometer at $520 \mathrm{~nm}$. Results were expressed in g galacturonic acid $100 \mathrm{~g}^{-1}$ edible portion [11, 12].

The fruits were harvested in the same individual (genotype) and the geographical arrangement of the plants was not suitable for an experimental design that could allow the use of analysis of variance. So the assays were performed in triplicate constituted by pulp from samples weighing at least $500 \mathrm{~g}$ and results were expressed as mean values \pm standard deviation.

\section{Results and discussion}

No studies were found in the literature describing the nutritional properties of six of the fruits included in this work: Copernicia prunifera (carnauba) and 
Euterpe edulis (jussara) (figure 2); Blepharocalyx salicifolius (murta, figure O); Mouririguianensis (gurguri), M. elliptica (puçá-coroa-de-frade) and M. pusa (puçápreto) (figure 5).

Only a few of the 18 fruits studied are presently grown in commercial orchards, although some species are marketed in processed forms such as jam, juice, nectar and, most often, frozen pulp. With regard to the latter, identity and quality standards have been determined by regulations issued by the Brazilian Ministry of Agriculture and Food Supply (MAPA) [13].

\subsection{Total soluble solids and sugars}

The fruits of the 18 species studied differed considerably in their solids and sugars content: TSS ranged from $4.75^{\circ}$ Brix (jussara) to 37.07 (carnauba), SS varied between 1.26\% (assai) and $17.74 \%$ (carnauba) and RS between 2.53\% (jussara) and 9.92\% (puçápreto) (table II). In general, our findings matched with results reported in the literature for assai, acerola, bacuri, camu-camu, jaboticaba, java plum, mangaba, nance, umbu uvaia and yellow mombin, [14-30].

Only five of the 18 fruits studied (assai, acerola, cashew apple, mangaba and yellow mombin) are specifically mentioned in the Brazilian legislation [13]. Pulps of the four latter fruits were found to be within the limits of solids and sugars established by law. No limits have been established for assai.

Total soluble sugars usually make up 65$85 \%$ of total soluble solids [31]. Our findings showed interspecies variation to be as large as $21 \%$ for assai and $89 \%$ for bacuri. Sugars play a very important role in the quality of fruit products. The most common types found in fruits are fructose and glucose (reducing) and saccharose (non-reducing). In most of our samples, sugars were predominantly of the reducing type. In seven species, RS represented 36\% (bacuri) to 88\% (jabuticaba and umbu) of total soluble sugars.

\subsection{Acidity and [TSS / TTA] ratio}

TTA and $\mathrm{pH}$ are the main acidity parameters of interest in fruits and vegetables. The $\mathrm{pH}$

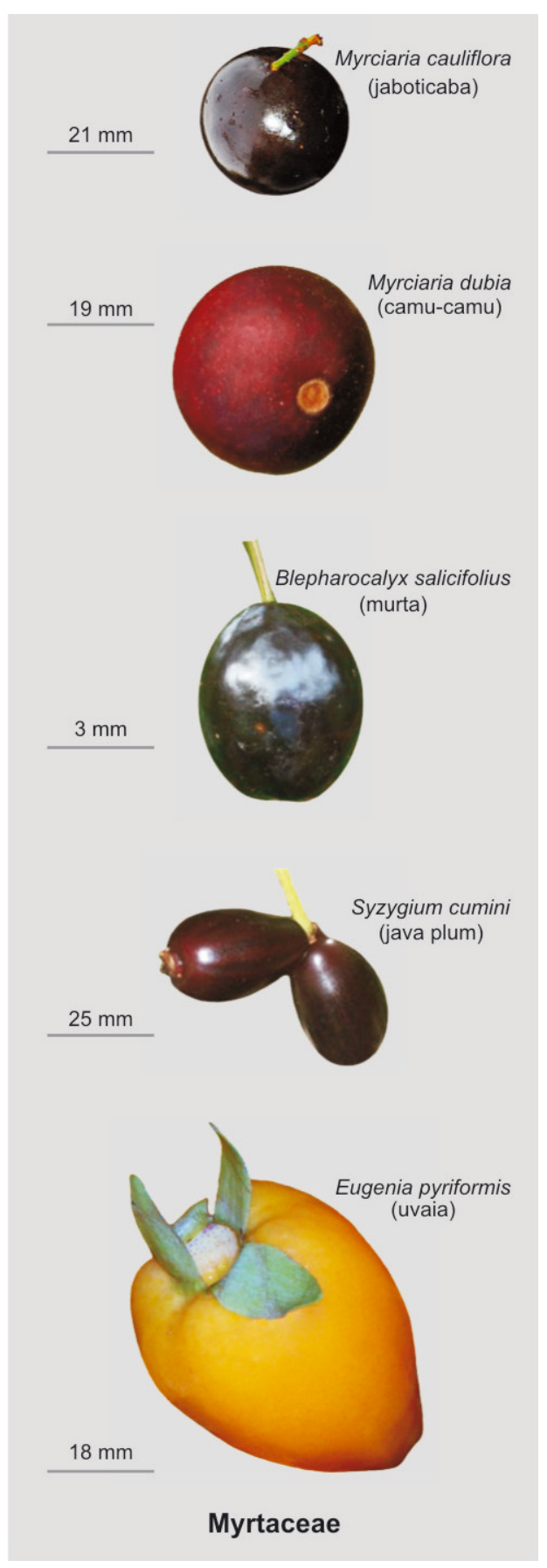

Figure 6.

Brazilian tropical, nontraditional fruits of the Myrtaceae family. measurement indicates the level of hydrogen ions in the juice, while TTA indicates the percentage of organic acid [31]. TTA values varied greatly in this study, from $0.20 \%$ for cashew apple to $2.92 \%$ for camu-camu (table II). Findings for these two fruits were 
Table I.

List of the 18 Brazilian tropical, non-traditional fruits included in a study aiming at assessing their quality for fresh consumption and processing.

\begin{tabular}{|c|c|c|c|c|}
\hline Brazilian name & English name & Scientific name & Family & Origin (city, state) \\
\hline Açaí & Assai & Euterpe oleracea & Arecaceae & Paraipaba, Ceará \\
\hline Acerola & Acerola & Malpighia emarginata & Malpighiaceae & Limoeiro do Norte, Ceará \\
\hline Bacuri & Bacuri & Platonia insignis & Clusiaceae & Coelho Neto, Maranhão \\
\hline Cajá & Yellow mombim & Spondias mombin & Anacardiaceae & Limoeiro do Norte, Ceará \\
\hline Caju & Cashew & Anacardium occidentale & Anacardiaceae & Pacajus, Ceará \\
\hline Camu-camu & Camu-camu & Myrciaria dubia & Myrtaceae & Belém, Pará \\
\hline Carnaúba & Carnauba & Copernicia prunifera & Arecaceae & Maracanaú, Ceará \\
\hline Gurguri & Gurguri & Mouriri guianensis & Melastomataceae & Beberibe, Ceará \\
\hline Jaboticaba & Jaboticaba & Myrciaria cauliflora & Myrtaceae & Serra de Ibiapaba, Ceará \\
\hline Jambolão & Java plum & Syzygium cumini & Myrtaceae & Trairi, Ceará \\
\hline Juçara & Jussara & Euterpe edulis & Arecaceae & São Paulo, São Paulo \\
\hline Mangaba & Mangaba & Hancornia speciosa & Apocynaceae & Ipiranga, Piauí \\
\hline Murici & Nance & Byrsonima dealbata & Malpighiaceae & Fortaleza, Ceará \\
\hline Murta & Murta & Blepharocalyx salicifolius & Myrtaceae & Crato, Ceará \\
\hline Puçá coroa de frade & Puçá-coroa-de-frade & Mouriri elliptica & Melastomataceae & Beberibe, Ceará \\
\hline Puçá-preto & Puçá-preto & Mouriri pusa & Melastomataceae & Ipiranga, Piauí \\
\hline Umbu & Umbu & Spondias tuberosa & Anacardiaceae & Picos, Piauí \\
\hline Uvaia & Uvaia & Eugenia pyriformis & Myrtaceae & Paraipaba, Ceará \\
\hline
\end{tabular}

in accordance with values reported in the literature [21, 32].

$\mathrm{pH}$ values ranged between 2.56 (camucamu) and 5.38 (assai). The pH value helps to determine the state of deterioration of most foodstuffs and is therefore associated with food quality and safety [33]. Based on the minimum $\mathrm{pH}$ (4.5) required for the multiplication and toxin production of Clostridium botulinum and the minimum $\mathrm{pH}$ (4.0) required for the proliferation of most bacteria, the 18 species evaluated in this study may be classified into slightly acid $(\mathrm{pH}>4.5$ : assai, carnauba, gurguri, jussara and puçá-preto), moderately acid ( $\mathrm{pH} 4.0$ 4.5: cashew apple, jussara, murta and puçácoroa-de-frade) and highly acid $(\mathrm{pH}<4.0)$ for the others [34].

As for TSS and SS, pulp produced with samples of the fruits for which regulations exist (assai, acerola, cashew apple, mangaba and yellow mombin) were found to be within the required standards of TTA and $\mathrm{pH}$ [13].

The [TSS / TTA] ratio indicates the level of sweetness in a foodstuff. It is one of the most common indicators of ripeness in fruits for in natura consumption or agroindustrial processing. The sweetest among the 18 fruits studied were carnauba ([TSS / TTA $]=07.70), \quad$ puçá-preto $\quad([T S S /$ TTA $]=75.98) \quad$ and cashew $\quad([T S S /$ TTA $]=58.79)$. Nevertheless, even fruits with low [TSS / TTA] ratios may be attractive sources of raw material, especially when a low [TSS / TTA] ratio is the result of a high level of acidity, that can be a desirable quality.

\subsection{Starch and pectin}

Only eight of the 18 fruits studied displayed starch contents below 1\% (table II). In general, total soluble solids and sugars increase as fruits ripen, making them more palatable. The process is associated with the hydrolysis of reserve starch by $\alpha$-amylase, $\beta$ amylase and/or phosphorylase [35], reducing starch contents to very low levels, sometimes to virtually zero.

In contrast, in some of our fruits, starch contents were surprisingly high, such as in carnauba $(12.65 \%)$, nance $(7.01 \%)$, assai 


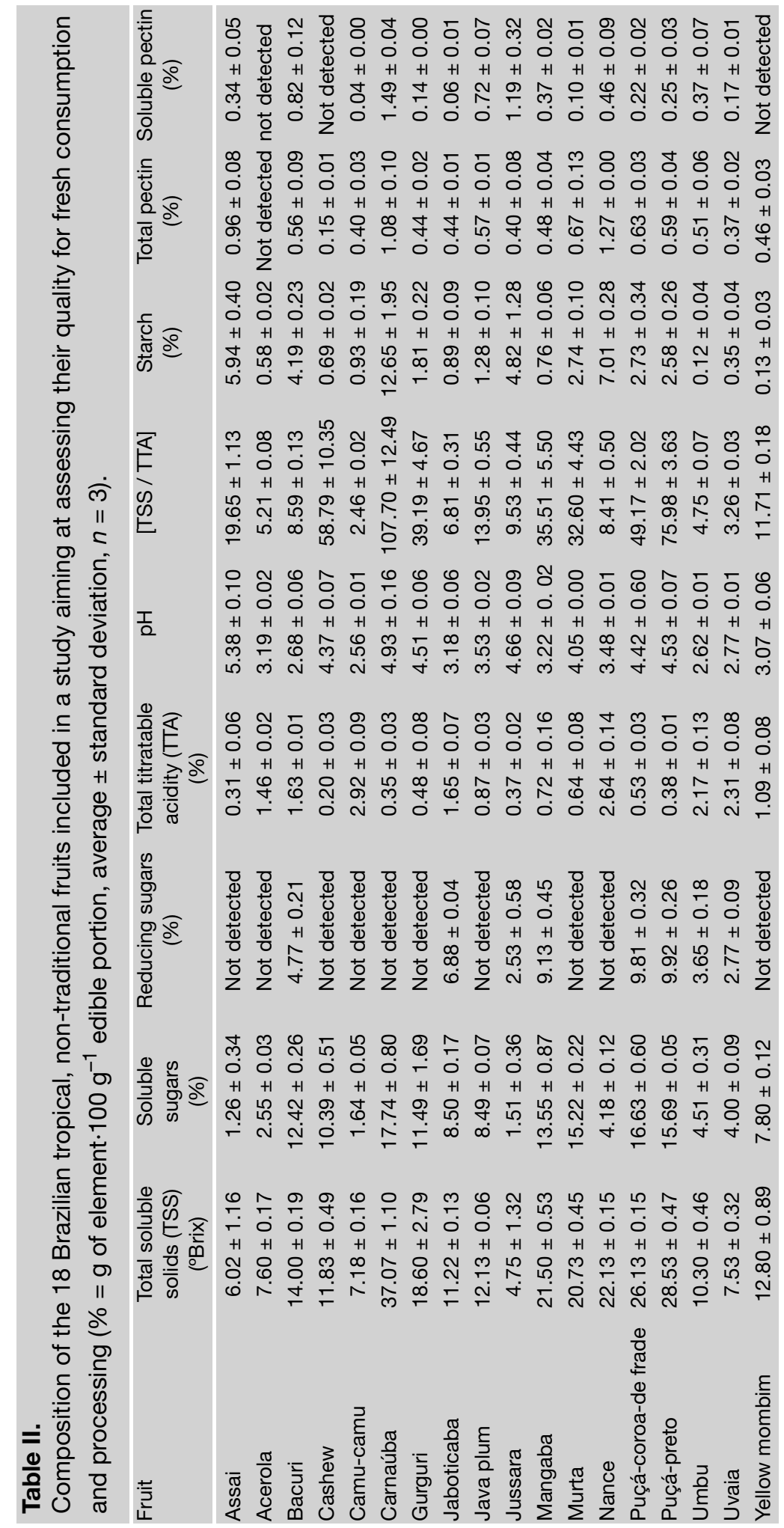


(5.94\%) and jussara (4.82\%). The starch in fruit pulp is associated with high energy levels and a texture appropriate for fresh consumption in a mashed form, most often mixed with cassava meal or equivalent regional ingredients [16].

From a nutritional point of view, the importance of starch lies in the fact that it may be partially or totally digested by the enzymes in the gastrointestinal tract and the resulting absorbed on the small bowel [36]. On the other hand, the relatively high starch contents (>1\%) observed in this study can make the juice and nectar processing and stabilization difficult and may impair consumer acceptance due to a starchy taste [16].

Pectin contents also varied from $0.15 \%$ (cashew apple) to $1.27 \%$ (nance) for total pectin, and from $0.04 \%$ (camu-camu) to $1.49 \%$ (carnauba) for soluble pectin (table II). Because pectins affect the texture and conservation of fruits, they are among the most essential ingredients of the agroindustry (especially in jam production) and confer palatability and attractive appearance on processed foods [31]. The high pectin and acidity contents in fruit pulps can favor gelling in jam production. On average, our fruits were low in pectins, with the exception of nance, carnauba and assai. On the other hand, high levels of pectin and starch can make manual pulp extraction difficult. One way to improve pulp yield is by using amylase- and pectinase-containing enzyme complexes in mechanical extraction [37].

\section{Conclusions}

The quality properties found for some of the eighteen fruits included in our study carried out on samples collected in Brazil clearly indicate a potential for in natura consumption and agroindustrial processing. Assai, acerola, cashew apple, mangaba and yellow mombin were found to be within or above standards required by the Brazilian Ministry of Agriculture and Food for fruit pulp produced from these fruits. However, the high levels of pectin and starch in some of the fruits can make juice and nectar production difficult, but this can be overcome by the introduction of enzyme complexes into the processing technique.

\section{Acknowledgements}

The authors would like to thank CNPq, CAPES, EMBRAPA, UFERSA and the European Union (INCO-CT-2005-015279) for financial support.

\section{References}

[1] Akinnifesi F.K., Leakey R.R.B., Ajayi O.C., Sileshi G., Tchoundjeu Z., Matakala P., Kwesiga F.R., Indigenous fruit trees in the tropics, CABI, London, UK, 2008.

[2] Janick J., Paull R.E., The encyclopedia of fruit and nuts, CABI, London, UK, 2008.

[3] Duch E.S., Frutas exóticas de la peninsula de Yucatán, CoSNET, Inst. Tecnol. Mérida, Mérida, México, 2001.

[4] Donadio L.C., Nachtigal J.C., Sacramento C.K., Frutas exóticas, Funep, Jaboticabal, Brazil, 1998.

[5] Oliveira M.S.P., Carvalho J.E.U., Nascimento W.M.O., Açaí (Euterpe oleracea Mart.), Funep, Jaboticabal, Brazil, 2000.

[6] Alves R.E, Souza F.X., Castro A.C.R., Rufino M.S.M., Ferreira E.G., Produção de fruteiras nativas, Inst. Frut., Fortaleza, Brazil, 2005.

[7] Anon., Official methods of analysis of the Association of Official Analytical Chemistry, AOAC, Washington, USA, 1992.

[8] Yemn E.W., Willis A.J., The estimation of carbohydrate in plant extracts by anthrone, Biochem. J. 57 (1954) 508-517.

[9] Miller G.L., Use of dinitrosalicylic acid reagent for determination of reducing sugars, Anal. Chem. 31 (1959) 426-428.

[10] Anon., Normas analíticas, métodos químicos e físicos para análise de alimentos, Inst. Adolfo Lutz (IAL), São Paulo, Brazil, 1985.

[11] McCready R.M., McComb E.A., Extraction and determination of total pectic material in fruits, Anal. Chem. 24 (1952) 1586-1588.

[12] Blumenkrantz N., Asboe-Hansen G., New method for quantitative determination of uronics acids, Anal. Biochem. 54 (1973) 484-489. 
[13] Anon., Instrução Normativa $N^{\circ} 01$, de 07 de janeiro de 2000, Anexo I. Diário Oficial [da] República Federativa do Brasil, Poder Exec., Seção 1, Brasília, DF, Brazil, 2000, p. 54.

[14] Aguiar L.P., Figueiredo R.W. de, Alves R.E., Maia G.A., Souza V.A.B., Caracterização física e físico-química de frutos de diferentes genótipos de bacurizeiro (Platonia insignis Mart.), Ciênc. Tecnol. Aliment. 28 (2008) 423-428.

[15] Alves R.E., Características das frutas para exportação, in: Acerola para exportação: procedimentos de colheita e pós-colheita, Embrapa/ Frupex, Brasília, Brazil, 1996.

[16] Alves R.E., Filgueiras H.A.C., Moura C.F.H., Caracterização de frutas nativas da América Latina, Sér. Frut. Nativ., Jaboticabal, Brazil, 2000.

[17] Alves R.E., Filgueiras H.A.C.. Moura C.F.H., Araújo N.C.C., Almeida A.S., Camu-camu (Myrciaria dubia Mc Vaugh): A rich natural source of vitamin C, Proc. Interam. Soc. Trop. Hortic. 46 (2002) 11-13.

[18] Donadio L.C., Study of some Brazilian myrtaceae in Jaboticabal-SP, Acta Hortic. 452 (1997) 181-183.

[19] Filgueiras H.A.C., Alves R.E., Oliveira A.C., Moura C.F.H., Araújo N.C.C., Calidad de frutas nativas de latinoamerica para industria: jobo (Spondias mombin L.), Proc. Interam. Soc. Trop. Hortic. 43 (2001) 72-76.

[20] Lago E.S., Gomes E., Silva R., Produção de geléia de jambolão (Syzygium cumini Lamarck): processamento, parâmetros físicoquímicos e avaliação sensorial, Ciênc. Tecnol. Aliment. 264 (2006) 847-852.

[21] Lourenço I.P., Potencial de utilização de frutos de genótipos de muricizeiros cultivados no litoral do Ceará, Univ. Fed. Ceará, Fortaleza, Brazil, Thesis, 2008, 98 p.

[22] Mendonça R.U. de, Qualidade e potencial de cajás (Spondias mombin L.) oriundos da região meio-norte do Brasil, Univ. Fed. Ceará, Fortaleza, Brazil, Thesis, 2004, 41 p.

[23] Moura C.F.H., Alves R.E., Filgueiras H.A.C., Araújo N.C.C., Almeida A.S., Quality of fruits native to Latin America for processing: Mangaba (Hancornia speciosa Gomes), Acta Hortic. 575 (2002) 549-554.

[24] Moura C.F.H., Alves R.E., Figueiredo R.W. de., Paiva J.R., Avaliações físicas e físicoquímicas de frutos de clones de aceroleira (Malpighia emarginata D.C.), Rev. Ciênc. Agron. 38 (2007) 52-57.
[25] Oliveira A.L., Brunini M.A., Salandini C.A.R., Bazzo F.R., Physicochemical characteristics of 'sabara' jaboticaba provenients of differents regions of cultivation, Rev. Bras. Frutic. 25 (2003) 397-400.

[26] Silva S.M., Moura F.T., Martins L.P., Silva M.S., Mendonça R.M.N., Alves R.E., Some physical and physico-chemical characteristics of imbu (Spondias tuberosa Arr. Câm.) fruit, Proc. Interam. Soc. Trop. Hortic. 45 (2001) 42-44.

[27] Souza M.C., Qualidade e atividade antioxidante de frutos de diferentes progênies de açaizeiro (Euterpe oleracea Mart.), Univ. Fed. Ceará, Thesis, 2007, 124 p.

[28] Souza F.G., Figueiredo R.W., Alves R.E., Maia G.A., Araújo I.A., Qualidade pós-colheita de frutos e diferentes clones de mangabeira (Hancornia speciosa Gomes), Ciênc. Agrotech. 31 (2007) 1449-1454.

[29] Cruz Pessoa J.D., Silva e Silva da P.V., Effect of temperature and storage on açaí (Euterpe oleracea) fruit water uptake: simulation of fruit transportation and pre-processing, Fruits 62 (5) 295-302.

[30] Assis de S.A., Fernandes F.P., Geraldo Martins A.B., Faria Oliveira de O.M.M., Acerola: importance, culture conditions, production and biochemical aspects, Fruits 63 (2) 93101.

[31] Chitarra A.B., Chitarra M.I.F., Pós-colheita de frutos e hortaliças: fisiologia e manuseio, UFLA, Lavras, Brazil, 2005.

[32] Abreu C.R.A., Qualidade e atividade antioxidante total de pedúnculos de clones comerciais de cajueiro anão precoce, Univ. Fed. do Ceará, Fortaleza, Brazil, Thesis, 2007, 111 p.

[33] Gomes J.C., Análise de alimentos, UFV, Viçosa, Brazil, 1996.

[34] Franco B.D.G.M., Landgraf M., Microbiologia dos alimentos, Atheneu, São Paulo, Brazil, 1996.

[35] Kays S.J., Postharvest physiology of perishable plant products, AVI Book, New York, USA, 1991.

[36] Tabernero M., Serrano J., Saura-Calixto F., Dietary fiber intake in two European diets with high (Copenhagen, Denmark) and low (Murcia, Spain) colorectal cancer incidence, J. Agric. Food Chem. 55 (2007) 9443-9449.

[37] Oke M., Paliyath G., Biochemistry of fruit processing, in: Hui Y.H. (Ed.), Fruit biochemistry and fruit processing, Blackwell, Ames, USA, 2006. 
Calidad de algunas frutas tropicales no-tradicionales brasileñas para consume en fresco y industrialización.

Resumen - Introducción. Brasil presenta una gran diversidad de frutales no-tradicionales con características promisorias tanto para el consumo en fresco cuanto para a industrialización. Tomándose en cuenta este potencial, el objetivo de ese trabajo fue evaluar la calidad de dieciocho especies de frutas tropicales no-tradicionales de ocurrencia en el país, oriundas de las siguientes familias botánicas: Anacardiaceae, Apocynaceae, Arecaceae, Clusiaceae, Malpighiaceae, Melastomataceae y Myrtaceae. Material y métodos. Los frutos fueran cosechados en áreas de ocurrencia, cultivos comerciales y colecciones en las regiones Norte, Noreste y Sureste del país y evaluados cuanto a las siguientes características de calidad: sólidos solubles totales (SST), azúcares solubles (AS) e reductores (RS), acidez total titulable (ATT), pH, relación [SST / ATT], almidón y pectina total (PT) y soluble (PS). Resultados y discusión. Fue observada una gran variación para todas las características evaluadas: SST: $4,75-37,07^{\circ}$ Brix, AS: $1,26-17,74 \%$, AR: 2,53-9,92 \%, ATT: 0,20-2,64\%, pH: 2,56-5,38, [SST / ATT] : 3,26-107,70, almidón: 0,12-12,65\%, PT: 0,15-1,27\% e PS: 0,04$1,49 \%$. Conclusión. Con bases en las características evaluadas pódense seleccionar frutas tanto para el consumo en fresco cuanto para la obtención de diferentes productos procesados.

Brasil / frutas tropicales / especies indigenas / variedades naturalizadas / producción potencial / consumo / frutas frescas / procesamiento 